OPEN ACCESS

Edited by: Alain Couvineau, Institut National de la Santé et de la Recherche Médicale (INSERM).

France

Reviewed by: Lili Ding,

Shanghai University of Traditional Chinese Medicine, China Mohamed El-Sherbiny, Almaarefa University, Saudi Arabia

*Correspondence: Hongyan Zuo zuohy2005@126.com

Yang Li

leeyoung109@hotmail.com

${ }^{+}$These authors have contributed equally to this work

Specialty section:

This article was submitted to Molecular and Structura Endocrinology, a section of the journa Frontiers in Endocrinology

Received: 06 September 2021 Accepted: 26 November 2021 Published: 21 December 2021

Citation:

Xing Y, Ye Y, Zuo H and Li Y (2021)

Progress on the Function and Application of Thymosin $\beta 4$.

Front. Endocrinol. 12:767785. doi: 10.3389/fendo.2021.767785

\section{Progress on the Function and Application of Thymosin $\beta 4$}

\author{
Yuan Xing ${ }^{1,2 \dagger}$, Yumeng $\mathrm{Ye}^{1 \dagger}$, Hongyan Zuo ${ }^{1 *}$ and Yang $\mathrm{Li}^{1,3^{*}}$ \\ ${ }^{1}$ Department of Experimental Pathology, Beijing Institute of Radiation Medicine, Beijing, China, ${ }^{2}$ Department of Pharmacy, \\ The First Affiliated Hospital of Hebei North University, Zhangjiakou, China, ${ }^{3}$ Academy of Life Sciences, Anhui Medical \\ University, Hefei City, China
}

Thymosin $\beta 4$ (Tß4) is a multifunctional and widely distributed peptide that plays a pivotal role in several physiological and pathological processes in the body, namely, increasing angiogenesis and proliferation and inhibiting apoptosis and inflammation. Moreover, Tß4 is effectively utilized for several indications in animal experiments or clinical trials, such as myocardial infarction and myocardial ischemia-reperfusion injury, xerophthalmia, liver and renal fibrosis, ulcerative colitis and colon cancer, and skin trauma. Recent studies have reported the potential application of T $\beta 4$ and its underlying mechanisms. The present study reveals the progress regarding functions and applications of T $\beta 4$.

Keywords: thymosin $\beta 4$, apoptosis, inflammation, signaling pathway, tissue repair, angiogenesis

\section{INTRODUCTION}

Thymosin is a lymphocyte growth factor that was initially extracted from the calf thymus by Goldstein and White (1). The thymosin family can be divided into three groups: $\alpha, \beta$, and $\gamma$ thymosin, based on the differences in their isoelectric point. The isoelectric point of thymosin $\beta$ (T $\beta$ ) is 5.0-7.0 (2). At present, 15 types of $\beta$-thymosin have been identified; of these, three main forms are found in the human body (T $\beta 4, \mathrm{~T} \beta 10$, and $\mathrm{T} \beta 15$ ), $\mathrm{T} \beta 4$ being the most abundant, accounting for $70 \%-80 \%$ of $\beta$-thymosin (3-5). T $\beta 4$ is found in various tissues, particularly in the thymus, spleen, and peritoneal macrophages (6)and is highly expressed in the brain, liver, kidney, testis, myocardium, platelets, and leukocytes (7).

\section{BIOLOGICAL FUNCTION OF T $\beta 4$}

$\mathrm{T} \beta 4$ comprises 43 amino acids and its biological activity is determined by encoded gene fragments. The first four amino acids of T $\beta 4$ regulate the anti-inflammatory and antifibrotic effects $(8,9)$, whereas amino acids 1-15 inhibit apoptosis and reduce the toxicity induced damage caused to cells (10). The active fragment encoded by amino acids 17-23 triggers angiogenesis and growth of hair follicles $(11,12)$.

\section{Tß34 Promotes Angiogenesis}

$\mathrm{T} \beta 4$ promotes angiogenesis, enhances endothelial progenitor cell (EPC) viability, and triggers the proliferation and migration of cells as well as formation of capillary-like structures in cells (13). Vascular endothelial growth factor (VEGF) is an important paracrine factor secreted by the 
progenitor cells to promote angiogenesis, which can further induce proliferation, differentiation, and migration of endothelial cells and increase vascular permeability. T $\beta 4$ upregulates VEGF expression, i.e., when T $\beta 4$-pretreated EPCs were transplanted into the infarcted rat heart, the expression of VEGF in the border region was markedly increased than that after EPC transplantation alone (14). The combination of T $\beta 4$ and human adipose-derived stem cells was used to treat hindlimb ischemia in mice. Moreover, T $\beta 4$ enhances the endothelial differentiation of these stem cells by upregulating various angiogenic factors, such as angiopoietin-1 and von Willebrand factor; furthermore, it triggers blood perfusion and collateral formation in the hindlimb by increasing the capillary density (15).

\section{Effects of T $\beta 4$ on Cell Proliferation and the Cell Cycle}

$\mathrm{T} \beta 4$ affects the cell cycle and promotes cell proliferation. After knocking-out $\mathrm{T} \beta 4$ in intestinal epithelial cells, cells slowly proliferated, cell cycle was affected indicating a marked decrease in the G0/G1 population and a remarkable increase in polyploid populations among these cells, and DNA replication was affected by DNA damage (16). Moreover, intrahippocampal infusion of $\mathrm{N}$-acetyl-erythritosyl-lysyl proline (a T $\beta 4$ peptide) facilitates the generation of new neurons in the hippocampus (17). T $\beta 4$ treatment enhances the proliferation of mesenchymal stem cells (MSCs), particularly those derived from adjacent adipose tissue, and interleukin (IL-8) crucially mediates T $\beta 4$ enhanced proliferation (18). Furthermore, T $\beta 4$ enhances the proliferation of oligodendrocyte progenitor cells (OPCs) and their maturation into myelinating oligodendrocytes (19). Furthermore, it stimulates the proliferation of adult rat cardiac progenitor cells and promotes their differentiation into vascular endothelial cells, coronary smooth muscle cells, and cardiomyocytes (20). Additionally, T $\beta 4$ accelerates vascular endothelial cell proliferation, thereby protecting post-ischemic cardiac function (21).

\section{Tß4 Inhibits Apoptosis}

T $\beta 4$ treatment alleviated tubular epithelial cell apoptosis by inhibiting the transforming growth factor (TGF)- $\beta$ pathway in Sprague-Dawley (SD) rats with chronic renal tubular interstitial fibrosis (22). Moreover, it prevents nucleus pulposus cell apoptosis, reduces cellular aging, and promotes cell proliferation (23). T $\beta 4$ further decreased the apoptosis rate of EPCs induced by serum depletion and markedly downregulated the expression of the apoptosis-related proteins caspase- 3 and caspase- 9 in EPCs (24). Furthermore, T $\beta 4$ prevented mitochondrial disruption and inhibited caspase-mediated apoptosis of human corneal epithelial cells exposed to ethanol in vitro, indicating that it may function as an antiapoptotic agent (25). In addition, T $\beta 4$ may inhibit neuronal apoptosis by upregulating glucose-regulated protein 78 and downregulating $\mathrm{C} / \mathrm{EBP}$ homologous protein and caspase-12, thereby reducing cerebral ischemia/reperfusion injury (26). In oxygen-glucose deprived and reoxygenated (OGD/R) cells, the rate of apoptosis was increased and GRP78, CHOP, and Bax were upregulated; however, Bcl-2 was downregulated, which was reversed by T $\beta 4$ overexpression. Moreover, T $\beta 4$ prevented OGD/R-induced endoplasmic reticulum stress-dependent apoptosis in cortical neurons (27). As T $\beta 4$ could attenuate the OGD/R-associated downregulation of P62 and Bcl-2 as well as the upregulation of autophagy mediators, such as autophagyrelated protein- 5 and the ratio of microtubule-associated protein 1 light chain 3, it effectively inhibited PC12 cell apoptosis and autophagy induced by OGD/R (28). Moreover, T $\beta 4$ treatment upregulated the expression of miR-200a; however, the increase in miR-200a downregulated the expression of p53 and reduced apoptosis of progenitor cells subjected to oxygen glucose deprivation (OGD) (29).

\section{T $\beta 4$ Ameliorates Inflammation}

T $\beta 4$ ameliorates inflammatory reactions. In a mouse model of autoimmune encephalomyelitis, hematoxylin-eosin staining showed markedly decreased the number of inflammatory cells in the brains of T $\beta 4$-treated mice (30). In models of liver injury mediated by ethanol and lipopolysaccharide, $T \beta 4$ prevented the activation of nuclear factor kappa $B(N F-\kappa B)$ by blocking the phosphorylation of the inhibitory protein $I \kappa B$, thereby preventing the production of proinflammatory cytokines such as tumor necrosis factor- $\alpha$ (TNF- $\alpha$ ), IL-1 $\beta$, and IL-6 (31). A neonatal mouse fetal alcohol spectrum disorder model revealed that T $\beta 4$ treatment effectively blocked the increase in ethanolinduced inflammatory factors and decreased the expression of TNF- $\alpha$ and IL-1 $\beta$ (32).

\section{Tß4 AND SIGNALING PATHWAYS}

$\mathrm{T} \beta 4$ affects the secretion of multiple cytokines and regulates various signaling pathways. It alleviates inflammatory damage by regulating the $\mathrm{NF}-\mathrm{\kappa B}$ and Toll-like receptor pathways and reducing the release of cytokines such as TNF- $\alpha$ and IL-1 receptor-associated kinases. During tissue repair, T $\beta 4$ regulates PI3K/Akt/eNOS, Notch, angiopoietin-1/Tie2, and other pathways. In addition, it also regulates various signaling pathways, such as the TGF- $\beta$ pathway to attenuate fibrosis and the Wnt pathway to promote hair follicle generation (Figure 1).

\section{PI3K/Akt/eNOS Pathway}

$\mathrm{PI} 3 \mathrm{~K} / \mathrm{Akt}$ is an important pathway associated with microangiogenesis, and plays a pivotal role in cell migration, cell survival, and angiogenesis $(33,34)$. PI3K/Akt is the upstream pathway of eNOS and affects its transcription and translation. eNOS increases the local mobilization of EPCs and participates in angiogenesis (35). Moreover, exogenous T $\beta 4$ stimulates EPC proliferation, migration, and adhesion via the PI3K/Akt/eNOS signal transduction pathway (36). After intraperitoneal injection of T $\beta 4$ in rats with cerebral ischemia and reperfusion, the level of Akt phosphorylation and the expression of eNOS in the cerebral cortex increased, regeneration of blood vessels around the infarction occurred, and the neurological function of the rats 


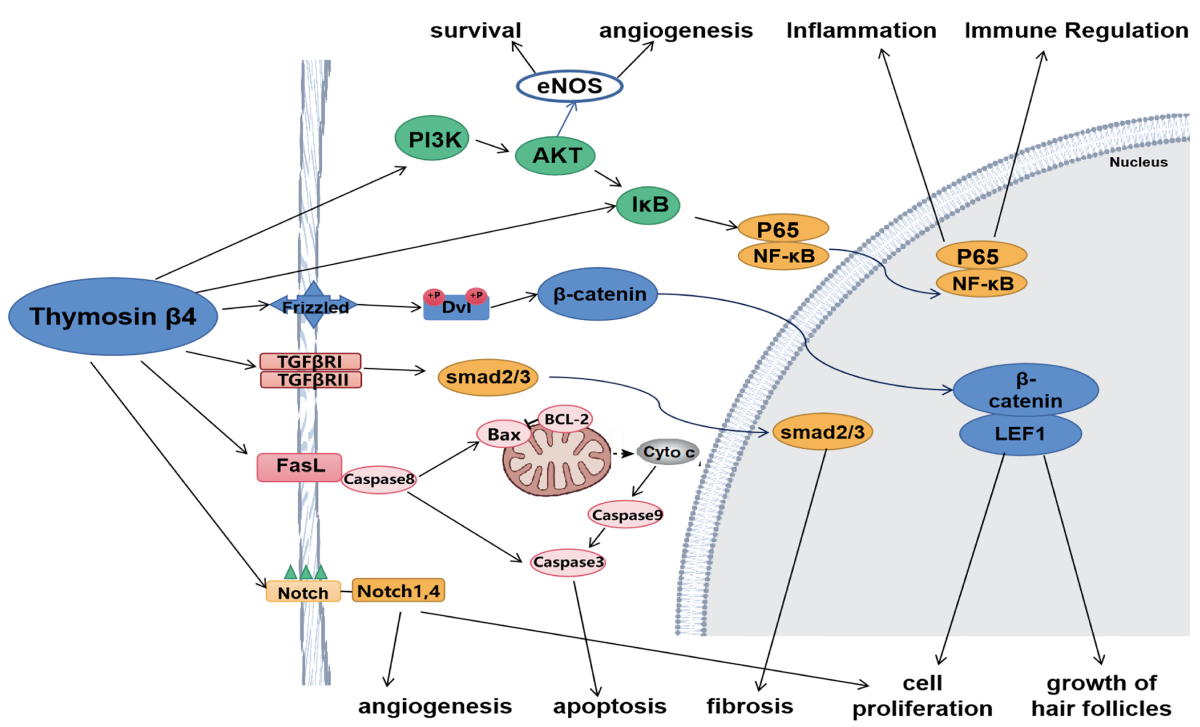

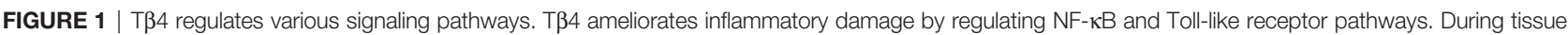
repair, T $\beta 4$ regulates PI3K/Akt/eNOS and Notch pathways. In addition, T $\beta 4$ regulates TGF- $\beta$ pathway to alleviate fibrosis and Wnt pathway to promote hair follicle formation. T $\beta 4$ also regulates apoptosis pathway to inhibit apoptosis.

was recovered (37). Furthermore, T $\beta 4$ induces angiogenesis via PI3K/AKT signaling pathway in ischemic limb diseases (38). Systemic injection of a T $\beta 4$-specific C-terminal tetrapeptide enhanced the early myocyte survival by activating Aktmediated signaling, increased coronary vessel growth, and inhibited inflammation in mice and pigs (39).

\section{Notch Pathway}

The Notch signaling pathway comprises four Notch receptors (Notch-1, 2, 3, 4, and 5) and five ligands (40). This pathway is crucial in neuronal function, tumor cell proliferation, apoptosis, angiogenesis, arterial endothelial cell stability, and expansion of bone marrow hematopoietic stem cells (41). T $\beta 4$ induces angiogenesis in human umbilical vein endothelial cells (HUVECs) via Notch signaling pathway. In the presence of T $\beta 4$, the expression of Notch1 and Notch4 increased in a doseand time-dependent manner and the speed of lumen formation was accelerated. When the Notch pathway is inhibited, the efficacy of T $\beta 4$ decreases (42). Moreover, T $\beta 4$ inhibited the proliferation and activation of hepatic stellate cells (HSCs), attenuated liver fibrosis by inhibiting Notch signaling, and markedly reduced expression levels of Notch2 and Notch3, which were increased in the liver cells (42). Furthermore, T $\beta 4$ enhanced HUVEC viability, angiogenesis, and migration, as well as promoted the expression of angiopoietin 2, VEGF A, Notch3, and other cytokines in HUVECs in a mouse model of critical limb ischemia (43). In addition, Takeshitak et al. (44) reported that endothelial-specific Notch1 knockdown mice had impaired neovascularization after hindlimb ischemia, and Notch1 induced angiogenesis without VEGF involvement (45). Recent studies reported that Notch signaling could also work in conjunction with VEGF and regulate VEGF expression (46-48). Shu Min et al. reported that Notch1 and Notch4 were required for Tb4- induced VEGF expression and angiogenesis. The downregulation of Notch1 or Notch4 by siRNA or DAPT inhibited Tb4-induced VEGF expression (42).

\section{TGF $\beta /$ Smad Pathway}

The TGF $\beta /$ Smad signaling pathway is crucially mediated by TGF $\beta$. In a model of fibrosis, TGF $\beta 1$ plays an important role in HSC activation (49). TGF $\beta 1$ initiates intracellular signal transduction by binding to the TGF $\beta$ receptor type II (TGF $\beta$ R II), and activates TGF $\beta$ receptor type I (TGF $\beta R$ I) kinase. Thereafter, TGF $\beta$ R I kinase activates the downstream proteins Smad2 and Smad3 via phosphorylation. Subsequently, Smad2, Smad3, and Smad4 form a complex and are transferred to the nucleus, where they increase the expression of various fibrotic genes, such as type I and type II collagen, tissue inhibitors of metalloproteinase- 1 and -2 (TIMP-1 and TIMP-2), and plasminogen activator inhibitor (PAI)-1 (50). Chen et al. reported that T $\beta 4$ reduced the expression of TGF- $\beta 1$, TGF $\beta R$ II, Smad2, and Smad3 in the liver tissues of mice with bile duct ligation. Moreover, they demonstrated that T $\beta 4$ reduced TGF $\beta R$ II expression level in human hepatic stellate cells LX-2 in vitro. These results indicated that $\mathrm{T} \beta 4$ alleviated cholestatic liver fibrosis by inhibiting the TGF $\beta /$ Smad pathway (51). Zhang et al. reported that $\mathrm{T} \beta 4$ treatment markedly inhibited the TGF $\beta 1 / K F-\kappa B$ signaling pathway, which affects neuroprotection and neurorestoration after traumatic brain injury (52).

\section{Wnt Signaling Pathway}

The Wnt signaling pathway is crucially associated with cell proliferation and differentiation and is functionally important for hair follicle morphogenesis (53). In the Wnt signaling pathway, Wnt ligands induce the phosphorylation of Disheveled to prevent GSK3 $\beta$-dependent phosphorylation of 
$\beta$-catenin (54). $\beta$-catenin and lymphokine-1 (Lef-1) are two key molecules in the Wnt signaling pathway (55). Gao et al. reported that T $\beta 4$ stimulated Wnt ligands on the cytomembrane to transmit the signal to accumulate unphosphorylated $\beta$-catenin for phosphorylation of Disheveled into the cytoplasm, which further leads to the accumulation of unphosphorylated $\beta$-catenin (56). In an epidermal-specific T $\beta 4$-overexpressing mouse model and $\mathrm{T} \beta 4$ global knockout mice, changes in $\beta$-catenin and Lef- 1 expression were similar to those of T $\beta 4$ (56). $\beta$-catenin plays a pivotal role in hair follicle growth. After $\mathrm{T} \beta 4$ treatment, the number of hair follicles in the mice significantly increased. Moreover, T $\beta 4$ can accelerate hair growth via Wnt signaling pathway by elevating the mRNA levels of $\beta$-catenin and Lef- 1 $(57,58)$. Additionally, T $\beta 4$ activates the $\mathrm{Wnt} /$ catenin signaling pathway in limb progenitor cells and promotes limb regeneration in a frog model (59). Furthermore, it protected Ang II-induced cardiomyocyte growth by regulating the Wnt pathway and Ang II stimulation, thereby leading to myocardial hypertrophy in mice. After T $\beta 4$ treatment, the cardiomyocyte area decreased, and the expression of hypertrophic marker genes, such as atrial natriuretic peptide, b-myosin heavy chain, $\beta$-catenin, and Wntmediated secretory protein-1, was decreased (60).

\section{Apoptosis Pathway}

The biological mechanism of apoptosis is extremely complex, involving the interaction of numerous proteins with signal transducers and signaling pathways. Members of the Bcl-2 protein family are responsible for regulating apoptosis (61). Previous studies have demonstrated that $\mathrm{T} \beta 4$ decreases apoptosis by increasing antiapoptotic proteins and reducing the Bax/BCL2 ratio (62). Sosne et al. demonstrated that T $\beta 4$ treatment decreased deleterious mitochondrial alterations, significantly decreased cytochrome c release from mitochondria, and increased Bcl-2 expression in ethanolexposed human corneal epithelial cells, wherein it inhibited the caspase-2, -3, -8, and -9 activity, with caspase- 8 exhibiting highest inhibition (63). Furthermore, FasL-mediated activation of caspases- 8 and -3 , as well as $\left.\left.\mathrm{H}_{2}\right) \mathrm{O}_{2}\right)$-triggered stimulation of caspases- 9 and -3 in human corneal epithelial T (HCE-T) cells was abolished by preincubating them with $\mathrm{T} \beta 4$ (64). Furthermore, Iguchi et al. combined the antitumor drugs with other drugs that interact with apoptotic processes, and found that after apoptosis, a low molecular weight protein, identified to be T $\beta 4$ by HPLC analysis, was commonly decreased, and the morphology of actin filaments changed into clump formations. These results indicate that decreased T $\beta 4$ expression induces apoptosis by antitumor drugs (65).

\section{APPLICATIONS OF T $\beta 4$ AND THE UNDERLYING MECHANISMS}

Due to its rich biological activity and anti-inflammatory effects, T $\beta 4$ regulates several inflammatory cytokines and chemokines and exerts therapeutic effects on various injuries or diseases such as corneal injury, xerophthalmia, and ulcerative colitis. T $\beta 4$ can reduce tissue fibrosis and can be used to treat pulmonary hypertension, pulmonary fibrosis, liver fibrosis, and renal fibrosis. Moreover, it can improve liver function and reduce glomerular injury. T $\beta 4$ can promote angiogenesis, tissue repair, and regeneration, and reduce scar formation. Furthermore, it can be used to promote wound healing, treat myocardial infarction and hindlimb ischemia, and heal damaged ligaments. In addition, T $\beta 4$ exhibits a strong antioxidant effect and can be used to treat cerebral or myocardial ischemia-reperfusion injury.

\section{Protective Effect of T $\beta 4$ on the Heart}

Myocardial infarction (MI) leads to sudden heart attack, and occurs during inappropriate flow of blood to a part of the heart, thereby causing injury to the heart due to lack of oxygen supply (66). MI has a high rate of disability and mortality, and is the leading cause of cardiac death (67).

$\mathrm{T} \beta 4$ reduces the infarct size and improves contractile performance in chronic myocardial ischemic injury through two phases: an acute phase that occurs immediately after injury, in which T $\beta 4$ preserves the ischemic myocardium via antiapoptotic or anti-inflammatory mechanisms, and a chronic phase, in which T $\beta 4$ activates the growth of vascular or cardiac progenitor cells (68). The clinical phase I trial evaluated the safety, tolerability, and pharmacokinetics of single and multiple intravenous injections of $\mathrm{T} \beta 4$ in healthy volunteers. No doselimiting toxicities or serious adverse events were observed. The tendency of terminal clearance in each dose group was consistent, and there was no obvious accumulation after continuous administration (69). These results were in accordance to those of another phase I clinical trial conducted by Ruff et al, wherein they evaluated the safety, incidence of treatment-emergent adverse events, and pharmacokinetic parameters of synthetic T $\beta 4$. Similarly, no dose-limiting toxicities or serious adverse events were observed (70). Subsequently, a phase II clinical trial was conducted in patients with acute myocardial infarction, which confirmed that T $\beta 4$ could protect and repair the heart and reduce the volume of scars after heart attack (71). In addition, Stromberg et al. conducted a safety trial of $\mathrm{T} \beta 4$ in children less than one year of age; thereafter, they conducted a randomized, double-blind clinical trial of T $\beta 4$ and placebo during congenital heart surgery. They evaluated the postoperative time to resolution of organ failure, development of low cardiac output syndrome, and echocardiographic index of cardiac dysfunction. These results confirm the clinical utility of $\mathrm{T} \beta 4$ in improving ischemia-reperfusion injury during congenital heart surgery (72).

Additionally, T $\beta 4$ attenuates rejection of the transplanted heart after heart transplantation. T $\beta 4$ in combination with adenovirus-associated vector 2.9 was used to treat rejection after heart transplantation. In this case, $T \beta 4$ reduced acute rejection, elevated the density of cardiac capillaries, increase survival rates of miniature pigs after heart transplantation, and markedly enhanced the local myocardial function of the grafts (73).

In addition, $\mathrm{T} \beta 4$ exhibits auxiliary functions, such as enhancing the therapeutic effect of MSCs and increasing the time of cardiac regeneration. Under hypoxic conditions, T $\beta 4$ 
$(1 \mu \mathrm{g} / \mathrm{mL})$ reduces the injury, apoptosis, and caspase- 8 activity of MSCs; however, it increases B-cell lymphoma-XL protein expression and MSC proliferation. In an in vivo experiment, the injection of MSCs containing T $\beta 4$ into the rat myocardium effectively restored the cardiac function after myocardial infarction, increased cardiac blood flow, and significantly improved survival rates of MSCs (74).

$\mathrm{T} \beta 4$ prolongs the time of heart regeneration in mammals. Hearts of 1-day-old mice regenerated after partial surgical resection, and this effect was lost by 7 days of age; however, $\mathrm{T} \beta 4$ could extend the cardiac regeneration potential of neonatal mice to the 7th postnatal day (75).

Transplantation of EPCs can repair the heart via angiogenesis or secretion of protective paracrine factors (76); however, transplantation of autologous EPCs has numerous limitations, including the limited supply of expanded EPCs, impaired function, and activity of the transplanted cells (77). Transplantation of T $\beta 4$-pretreated EPCs to the injured heart could treat acute ST-segment elevation in myocardial infarction. The cardiac function of the T $\beta 4$ group was significantly improved compared with that of the control group, and no serious complications were observed (78).

Considering the underlying mechanisms of protective role of $\mathrm{T} \beta 4$ in heart injuries, previous studies reported that treatment with T $\beta 4$ in the myocardial infarction setting improves cardiac function by activating Akt phosphorylation, promoting the ILKPinch-Parvin complex, and suppressing NF- $\kappa B$. Furthermore, $\mathrm{T} \beta 4$ selectively upregulates catalase, $\mathrm{Cu} / \mathrm{Zn}-\mathrm{SOD}$, and $\mathrm{Bcl} 2$, thereby protecting cardiac fibroblasts from $\mathrm{H}_{2} \mathrm{O}_{2}$ induced oxidative damage (79). In the myocardial infarction model, $\mathrm{T} \beta 4$ enhanced cardiac function by suppressing NF- $\kappa \mathrm{B}$, thereby attenuating cardiac fibrosis $(80,81)$.

In summary, T $\beta 4$ exerts therapeutic effects on various heartrelated diseases such as myocardial infarction and myocardial ischemia-reperfusion injury, indicating that it may be used as a promising drug for the clinical treatment of heart diseases in the future.

\section{Therapeutic Effects of T $\beta 4$ on Corneal Injury and Dry Eye Syndrome}

Recent studies have reported that $T \beta 4$ exerts a therapeutic effect on corneal injury and dry eye syndrome. Corneal injuries are common in chemical burns and oxidative injuries. Some chemicals can quickly lead to corneal stromal dissolution, activate stromal fibroblasts, cause a large amount of inflammatory cell infiltration, and eventually lead to corneal ulcers and perforations, which can lead to blindness (82).

T $\beta 4$ can affect the secretion of numerous cytokines, promote corneal re-epithelialization, dampen untoward inflammation, and inhibit apoptosis; thus, it exerts therapeutic effect on corneal injury (83). Moreover, it can reduce corneal inflammation and regulate the balance of cellular matrix metalloproteinases and tissue inhibitors of metalloproteinases, thus promoting corneal wound repair after alkaline injury and improving corneal transparency. In various corneal injury models, such as chemical injury and corneal epithelial debridement, T $\beta 4$ exhibited strong anti-inflammatory and wound healing effects (84). Recombinant $\mathrm{T} \beta 4$ treatment of corneal burns in rabbits revealed that recombinant $\mathrm{T} \beta 4$ effectively promoted newborn tissue remodeling and corneal burn repair, as recombinant $\mathrm{T} \beta 4$ regulates the expression of MMP-2 and TIMP-2 to promote tissue repair (85). In a model of hydrogen peroxide-induced oxidative corneal injury, T $\beta 4$ promoted the growth and migration of rabbit corneal epithelial cells, reduced apoptosis, enhanced antioxidant capacity, and exerted a strong protective effect on damaged corneas (86).

Dry eye syndrome is a common ophthalmic disease characterized by ocular surface inflammation (87). T $\beta 4$ can slow eye dryness and accelerate wound healing. It markedly alleviated xerophthalmia symptoms in a mouse model. A randomized double-blind clinical phase II trial revealed that the $\mathrm{T} \beta 4$ treatment group revealed a $35.1 \%$ reduction in ocular discomfort than that of the vehicle control group and a $59.1 \%$ reduction in total corneal fluorescein staining than that of the vehicle control group. Other improvements observed in T $\beta 4$ treated patients included tear film breakup time and increased tear volume production (88). Furthermore, glycine T $\beta 4$ eye drops significantly increased conjunctival goblet $\mathrm{T}$ cells, significantly decreased corneal cell apoptosis, and reduced inflammatory cytokine levels and $\mathrm{T}$ cells in the conjunctiva (89). A randomized double-blind clinical phase II trial conducted by Sosne et al. revealed that eye discomfort in the $\mathrm{T} \beta 4$ treatment group was reduced by $35.1 \%$ than that in the control group, and the total corneal fluorescein staining was reduced by $59.1 \%$. In addition, improvement in tear film breakup time and increase in tear volume was observed in T $\beta 4$-treated patients (88).

\section{T $\beta 4$ Promotes Skin Wound Healing}

Wound healing includes angiogenesis, cell proliferation, differentiation, migration, epithelial reconstruction, and wound closure, by various cytokines. Although the design of skin flaps and surgical techniques are constantly improving, ischemic necrosis remains a common clinical problem (90). T $\beta 4$ can promote cell migration and angiogenesis, regulate various cytokines, such as intercellular adhesion molecule (ICAM-1), MMP, laminin (LN), VEGF, and basic fibroblast growth factor, inhibit apoptosis, eliminate inflammation, and reduce oxidative damage $(91,92)$. Moreover, it can increase cell migration in various injury models, particularly the migration of keratinocytes, which cover the wound and protect from fluid loss and infection (81, 93-96). Male Sprague-Dawley rats were subjected to random-pattern skin flap operations. T $\beta 4$ significantly reduced necrotic areas; rats that received $5 \mathrm{mg} / \mathrm{kg}$ T $\beta 4$ twice per day presented the highest survival rates. VEGF expression and superoxide dismutase activity were markedly increased, whereas malondialdehyde levels were reduced (97). In a full-thickness skin defect Sprague-Dawley rats rat model, VEGF and basic fibroblast growth factor revealed sustained and stable high expression after treatment with recombinant $\mathrm{T} \beta 4$, which inhibited LN-5 expression in the early stage, beneficial for cell proliferation and differentiation; furthermore, it upregulated LN-5 expression in the middle and late stages, which was beneficial for improving the matrix environment and 
promoting epidermal cell migration and wound healing (98). Additionally, T $\beta 4$ improved burn wound healing and promoted angiogenesis and wound closure, which may be associated with the long-term expression of heat shock protein 70, related to Factin regulation during the wound-healing period (99). In addition, T $\beta 4$ associates actin polymerization with metalloproteinase synthesis to promote cell migration. One mechanism proposes that profilin-dependent dissociation of the G-actin-T $\beta 4$ complex liberates actin for filament assembly (96). T $\beta 4$ binds to integrin-linked kinase in the lamellipodia to activate Akt2 and increase metalloproteinase production (100). Moreover, it increases laminin-332 synthesis, which is a known migration factor for various epithelial and endothelial cells, including keratinocytes $(101,102)$. Collectively, T $\beta 4$ has the potential to heal and regenerate dermal injuries, and been successfully used in several clinical trials. Fine et al. organized a randomized double-blind clinical trial to determine whether $\mathrm{T} \beta 4$ may be beneficial in promoting wound healing in patients with epidermolysis bullosa (EB). A solitary noninfected cutaneous wound of standardized size was treated on a daily basis with either one of three doses of T $\beta 4$ or a placebo control. Simultaneously, the occurrence of adverse effects was sought to confirm the safety of $\mathrm{T} \beta 4$ when applied to EB skin, both in children and adults. Furthermore, the occurrence of adverse reactions was studied to confirm the safety of $\mathrm{T} \beta 4$ when applied to EB skin. Although it has not been proven, topical T $\beta 4$ may be an extremely important supplement in the overall management of patients with this potentially devastating disease (103). Phase II clinical trials for the use of T $\beta 4$ in epidermolysis bullosa, pressure sores, and venous stasis ulcers have been completed. Treadwel et al. organized 143 patients with chronic cutaneous (stage III/IV) pressure ulcers (full thickness) and venous stasis ulcers; results revealed that $\mathrm{T} \beta 4$ accelerated healing by almost a month in patients who healed (104). Another double-blind, placebo-controlled, dose-escalation study was conducted at eight locations in Europe. This study recruited 73 randomly assigned patients. The study reported that $\mathrm{T} \beta 4$ had the potential to accelerate wound healing, and approximately $25 \%$ of patients could heal completely within 3 months, particularly those with small to moderate wounds (105).

\section{Protective Effect of T $\beta 4$ on the Liver}

$\mathrm{T} \beta 4$ does not bind to heparin; therefore, it can spread freely into the tissue. It ameliorated carbon tetrachloride (CCl4)-induced acute liver injury in mice in a dose- and time-dependent manner by suppressing oxidative stress, inhibiting the inflammatory response, and reducing hepatocellular apoptosis (106). Moreover, T $\beta 4$ prevented ethanol- and lipopolysaccharide-mediated oxidative stress by decreasing reactive oxygen species and lipid peroxidation, increasing antioxidant levels, and reducing glutathione and manganese-dependent superoxide dismutase.

Liver fibrosis typically occurs in response to hepatic injury. It is characterized by collagen and extracellular matrix protein deposition in the liver tissues (107). Activated HSCs are responsible for collagen deposition and play a pivotal role in hepatic fibrogenesis (108). Several studies have reported that $\mathrm{T} \beta 4$ treatment has an antifibrotic effect on the liver $(51,109-111)$. Li et al. found that $T \beta 4$ could markedly reduce hydroxyproline content and collagen deposition in the livers of CCl4-induced mice and rats, and relieve liver and pseudo-lobule necrosis, whereas the inhibition of NF- $\mathrm{KB}$ p 65 might be an underlying mechanism (112). Chen et al. reported that in bile duct ligation mice, exogenous $\mathrm{T} \beta 4$ treatment reduced collagen deposition and suppressed $\alpha$-SMA expression, a marker of HSC activation, indicating that exogenous $\mathrm{T} \beta 4$ treatment hindered HSC activation to inhibit cholestatic liver fibrosis (51). Barnaeva et al. (109) demonstrated that T $\beta 4$-treated HSCs upregulated HGF and downregulated PDGF- $\beta$ receptor at the RNA level. Reyes-Gordillo et al. reported that $\mathrm{T} \beta 4$ treatment prevented PDGF- $\beta \beta$-dependent proliferation and migration of cultured human HSCs by inhibiting PDGF- $\beta \beta$-dependent phosphorylation of AKT. They found that T $\beta 4$ interrupted the movement of AKT into PI3K, blocking the phosphorylation of AKT by PI3K in HSCs treated with PDGF- $\beta \beta$ (110).

\section{Tß4 Promotes Hair Growth}

In recent years, $\mathrm{T} \beta 4$ has been closely related to hair follicle development and hair growth. Topical application of $T \beta 4$ promotes hair growth in rats and mice and it stimulates early differentiation of rat epithelial progenitor cells (113). Moreover, $\mathrm{T} \beta 4$ may act on hair follicle reconstruction by upregulating fibronectin expression in human dermal papilla cells (114). After shaving, the hair of $\mathrm{T} \beta 4$-overexpressing transgenic mice grew faster and longer than those of wild-type mice (115). Moreover, in aged mice with sparse hair, T $\beta 4$ accelerated hair growth for more than 26 weeks. After topical administration of $\mathrm{T} \beta 4$, the hair of nude mice grew faster and thicker than those of normal mice (113). T $\beta 4$ accelerates hair growth by increasing the proliferation of outer hair follicle root sheath cells, that is, hair follicles grew better and proliferated faster in the $T \beta 4$ group than in the control group when the outer hair follicle root sheath cells were cultured in vitro (116).

\section{Tß4 Alleviates Renal Fibrosis}

Chronic kidney disease is characterized by abnormalities in renal structure or function that last for more than 3 months and has an adverse impact on the health of the patient (117). Endogenous T $\beta 4$ is dispensable in healthy kidneys. In contrast, a lack of endogenous $\mathrm{T} \beta 4$ exacerbated symptoms in mouse models of glomerular disease and angiotensin II-induced renal injury. The administration of exogenous T $\beta 4$ or its metabolite Ac-SDKP revealed therapeutic effects various experimental models of kidney disease, such as glomerulonephritis, diabetic nephropathy, and hypertensive nephropathy (118). In renal fibrosis, T $\beta 4$ is upregulated in glomerulosclerosis and is required for the angiotensin II-induced expression of plasminogen activator inhibitor-1) PAI-1 (119). In addition, $\mathrm{T} \beta 4$ treatment might alleviate renal fibrosis and tubular epithelial cell apoptosis by inhibiting the TGF- $\beta$ pathway in rats with unilateral ureteral obstruction and chronic renal tubular interstitial fibrosis (22).

\section{Effect of T $\beta 4$ on Ulcerative Colitis and Colon Cancer}

$\mathrm{T} \beta 4$ is expressed in the human intestine, where it modulates the intestinal immune system (120). Moreover, it is considered to be 
TABLE 1 | Actions of T $\beta 4$ and mechanisms.

\begin{tabular}{|c|c|c|c|c|c|}
\hline $\begin{array}{l}\text { Encoded } \\
\text { gene } \\
\text { fragments }\end{array}$ & Actions & $\begin{array}{l}\text { Target } \\
\text { tissue }\end{array}$ & Indications & Mechanism & References \\
\hline $\begin{array}{l}1-4 \text { amino } \\
\text { acids }\end{array}$ & $\begin{array}{l}\text { anti- } \\
\text { inflammatory }\end{array}$ & brain & $\begin{array}{l}\text { autoimmune } \\
\text { encephalomyelitis }\end{array}$ & suppresses the secretion of interleukin-8 and the activation of NF-кB significantly. & $(30)$ \\
\hline $\begin{array}{l}\text { 1-4 amino } \\
\text { acids }\end{array}$ & $\begin{array}{l}\text { anti- } \\
\text { inflammatory }\end{array}$ & liver & $\begin{array}{l}\text { ethanol- and } \\
\text { LPS-induced liver } \\
\text { injury }\end{array}$ & $\begin{array}{l}\text {,inhibits the activation of NF- } \mathrm{B} \text { p pathway, thereby preventing the production of proinflammatory } \\
\text { cytokines, such as tumor necrosis TNF- } \alpha, \mathrm{IL}-1 \beta \text {, and IL- } 6 \text {. }\end{array}$ & (31) \\
\hline $\begin{array}{l}1-4 \text { amino } \\
\text { acids }\end{array}$ & $\begin{array}{l}\text { anti- } \\
\text { inflammatory }\end{array}$ & brain & $\begin{array}{l}\text { fetal alcohol } \\
\text { spectrum } \\
\text { disorders }\end{array}$ & $\begin{array}{l}\text { attenuates p38, ERK MAPKs, and NF-B pathway activation, and enhance miR-339-5p } \\
\text { expression induced by ethanol exposure in microglia. }\end{array}$ & $(32)$ \\
\hline $\begin{array}{l}1-4 \text { amino } \\
\text { acids }\end{array}$ & $\begin{array}{l}\text { anti- } \\
\text { inflammatory }\end{array}$ & eye & $\begin{array}{l}\text { dry eye } \\
\text { syndrome }\end{array}$ & reduces IL-1 $\beta, \mathrm{IL}-6, \mathrm{TNF}-\alpha$ and IFN- $\gamma$ and $\mathrm{CD} 4^{+} / \mathrm{CCR} 5^{+} \mathrm{T}$ cells. & (89) \\
\hline $\begin{array}{l}1-4 \text { amino } \\
\text { acids }\end{array}$ & $\begin{array}{l}\text { anti- } \\
\text { inflammatory }\end{array}$ & liver & $\begin{array}{l}\text { hepatic ischemia- } \\
\text { reperfusion injury }\end{array}$ & activates AKT-Bad pathway and inhibits the expression of TNF- $\alpha$ and IL-6. & $(97)$ \\
\hline $\begin{array}{l}1-4 \text { amino } \\
\text { acids }\end{array}$ & anti-fibrosis & liver & liver fibrosis & $\begin{array}{l}\text { inhibits the Notch signaling, reduces the expression of NF- } \mathrm{kB} \text { p65, inhibits PDGF- } \beta \text {-dependent } \\
\text { phosphorylation of AKT, and interrupts the movement of AKT into PI3K. }\end{array}$ & $\begin{array}{l}(110,112, \\
133)\end{array}$ \\
\hline $\begin{array}{l}1-4 \text { amino } \\
\text { acids }\end{array}$ & anti- fibrosis & kidney & renal fibrosis & inhibits the TGF- $\beta$ pathway. & $(22)$ \\
\hline $\begin{array}{l}1-15 \\
\text { amino } \\
\text { acids }\end{array}$ & $\begin{array}{l}\text { anti- } \\
\text { apoptosis }\end{array}$ & brain & $\begin{array}{l}\text { cerebral } \\
\text { ischemia/ } \\
\text { reperfusion injury }\end{array}$ & upregulates GRP78 and downregulates CHOP and caspase- 12. & $(26)$ \\
\hline $\begin{array}{l}1-15 \\
\text { amino } \\
\text { acids }\end{array}$ & $\begin{array}{l}\text { anti- } \\
\text { apoptosis }\end{array}$ & brain & $\begin{array}{l}\text { diseases } \\
\text { associated with } \\
\text { demyelination } \\
\text { disorders }\end{array}$ & $\begin{array}{l}\text { up-regulates miR-200a, increases MBP synthesis after targeting Grb2 and thereby inactivating } \\
\text { C-Jun from inhibition of MBP synthesis; and inhibits OGD-mediated apoptosis after targeting } \\
\text { EGFR inhibitor (Mig-6), PI3K inhibitors (FOG2 and Pten) and an inducer (p53) of pro-apoptotic } \\
\text { genes, for AKT activation and down-regulation of p53. }\end{array}$ & (29) \\
\hline $\begin{array}{l}1-15 \\
\text { amino } \\
\text { acids }\end{array}$ & $\begin{array}{l}\text { anti- } \\
\text { apoptosis }\end{array}$ & heart & $\begin{array}{l}\text { myocardial } \\
\text { infarction }\end{array}$ & reduces caspase- 8 activity, increases Bcl-XL protein expression. & $(74)$ \\
\hline $\begin{array}{l}1-15 \\
\text { amino } \\
\text { acids }\end{array}$ & $\begin{array}{l}\text { anti- } \\
\text { apoptosis }\end{array}$ & heart & $\begin{array}{l}\text { cardiovascular } \\
\text { disorders }\end{array}$ & $\begin{array}{l}\text { decreases the expression and activity of caspase- } 3 \text { and }-9 \text {, which markedly increased the Bcl- } \\
\text { 2/Bax ratio, and ILK-Akt activation. }\end{array}$ & (24) \\
\hline $\begin{array}{l}1-15 \\
\text { amino } \\
\text { acids }\end{array}$ & $\begin{array}{l}\text { anti- } \\
\text { apoptosis }\end{array}$ & eye & corneal diseases & $\begin{array}{l}\text { decreases FasL-mediated activation of caspases- } 8 \text { and }-3 \text { as well as } \mathrm{H}(2) \mathrm{O}(2) \text {-triggered } \\
\text { stimulation of caspases- } 9 \text { and }-3 \text {. }\end{array}$ & $(64)$ \\
\hline $\begin{array}{l}1-15 \\
\text { amino } \\
\text { acids }\end{array}$ & $\begin{array}{l}\text { anti- } \\
\text { apoptosis }\end{array}$ & eye & vision disorder & inhibits caspase-2, $-3,-8$, and -9 activity. & (63) \\
\hline $\begin{array}{l}1-15 \\
\text { amino } \\
\text { acids }\end{array}$ & $\begin{array}{l}\text { anti- } \\
\text { apoptosis }\end{array}$ & colon & Crohn's disease & $\begin{array}{l}\text { decreases TNF- } \alpha, I L-1 \beta \text { and IL-10 and decreases MPO activity and MDA content, increases } \\
\text { SOD activity. }\end{array}$ & $(122)$ \\
\hline $\begin{array}{l}17-23 \\
\text { amino } \\
\text { acids }\end{array}$ & $\begin{array}{l}\text { promotes } \\
\text { hair growth }\end{array}$ & $\begin{array}{l}\text { hair } \\
\text { follicle }\end{array}$ & depilation & $\begin{array}{l}\text { accelerates hair growth through the Wnt signaling pathway by increasing the mRNA levels of } \beta \text { - } \\
\text { catenin and Lef-1. }\end{array}$ & (58) \\
\hline $\begin{array}{l}17-23 \\
\text { amino } \\
\text { acids }\end{array}$ & $\begin{array}{l}\text { improves } \\
\text { wound } \\
\text { healing }\end{array}$ & skin & $\begin{array}{l}\text { full-thickness skin } \\
\text { defect SD rat } \\
\text { model }\end{array}$ & regulates VEGF, bFGF and LN-5. & (98) \\
\hline $\begin{array}{l}17-23 \\
\text { amino } \\
\text { acids }\end{array}$ & $\begin{array}{l}\text { improves } \\
\text { wound } \\
\text { healing }\end{array}$ & skin & $\begin{array}{l}\text { mouse burn } \\
\text { model }\end{array}$ & $\begin{array}{l}\text { Upregulates the expression of heat-shock proteins (HSP70), p-AKT and VEGF signaling } \\
\text { pathways. }\end{array}$ & (99) \\
\hline $\begin{array}{l}17-23 \\
\text { amino } \\
\text { acids }\end{array}$ & $\begin{array}{l}\text { stimulates } \\
\text { angiogenesis }\end{array}$ & heart & $\begin{array}{l}\text { myocardial } \\
\text { infarction }\end{array}$ & $\begin{array}{l}\text { upregulates the expression of VEGF, } \\
\text { activates Akt-mediated signaling, promotes the ILK-Pinch-Parvin complex, and suppresses NF- } \\
\kappa B \text {. }\end{array}$ & $(14,39,79)$ \\
\hline $\begin{array}{l}17-23 \\
\text { amino } \\
\text { acids }\end{array}$ & $\begin{array}{l}\text { stimulates } \\
\text { angiogenesis }\end{array}$ & $\begin{array}{l}\text { hind } \\
\text { limb }\end{array}$ & $\begin{array}{l}\text { hindlimb } \\
\text { ischemia }\end{array}$ & $\begin{array}{l}\text { upregulates various angiogenic factors, such as angiopoietin-1 and von Willebrand factor, } \\
\text { activates the PI3K/AKT signaling pathway, promotes the expression of angiopoietin2, VEGFA, } \\
\text { Notch3 and other cytokines in HUVECs }\end{array}$ & $(15,38,43)$ \\
\hline $\begin{array}{l}17-23 \\
\text { amino } \\
\text { acids }\end{array}$ & $\begin{array}{l}\text { stimulates } \\
\text { angiogenesis }\end{array}$ & brain & $\begin{array}{l}\text { cerebral ischemia } \\
\text { and reperfusion }\end{array}$ & $\begin{array}{l}\text { increases the level of Akt phosphorylation and the expression of eNOS in the cerebral cortex, } \\
\text { and regenerates blood vessels around the infarction. }\end{array}$ & (37) \\
\hline $\begin{array}{l}40-43 \\
\text { amino } \\
\text { acids }\end{array}$ & $\begin{array}{l}\text { increases } \\
\text { heart } \\
\text { function } \\
\text { post- } \\
\text { ischemia }\end{array}$ & heart & $\begin{array}{l}\text { rat model of } \\
\text { acute myocardial } \\
\text { ischemia- } \\
\text { reperfusion }\end{array}$ & decreases the level of MDA in serum and myocardial tissue and increases the activity of SOD. & (132) \\
\hline
\end{tabular}


TABLE 2 | Clinical trials of T $\beta 4$.

\begin{tabular}{|c|c|c|c|c|c|c|c|}
\hline Phase & Drug & Indications & Participants & Dosage regimen & Conclusions & Status & References \\
\hline I & $\begin{array}{l}\text { chemosynthetic } \\
\text { Thymosin } \beta 4\end{array}$ & $\begin{array}{l}\text { acute } \\
\text { myocardial } \\
\text { infarction }\end{array}$ & 40 healthy volunteers & $\begin{array}{l}42,140,420 \text {, or } 1260 \mathrm{mg} / \\
\mathrm{kg} \text { intravenous injections for } \\
14 \text { days. }\end{array}$ & $\begin{array}{l}\text { There were no dose limiting toxicities or } \\
\text { serious adverse events. }\end{array}$ & completed & (70) \\
\hline I & $\begin{array}{l}\text { Recombinant } \\
\text { Human } \\
\text { Thymosin } \beta 4\end{array}$ & $\begin{array}{l}\text { acute } \\
\text { myocardial } \\
\text { infarction }\end{array}$ & 54 healthy volunteers & $\begin{array}{l}0.05,0.25,0.5,2.0,5.0 \text {, } \\
12.5 \text { or } 25.0 \mu \mathrm{g} / \mathrm{kg} \text { in the } \\
\text { single-dose intravenous } \\
\text { injections trial and } \\
\text { in the multiple-dose } \\
\text { intravenous injections trial, } \\
0.5,2.0 \text { and } 5.0 \mu \mathrm{g} / \mathrm{kg} \\
\text { were administered once rh- } \\
\text { T } \beta 4 \text { daily for } 10 \text { days }\end{array}$ & $\begin{array}{l}\text { It was well tolerated and safe in healthy } \\
\text { people and suitable for use in a clinical } \\
\text { study for the treatment of acute } \\
\text { myocardial infarction. }\end{array}$ & completed & (69) \\
\hline ॥ & $\begin{array}{l}\text { chemosynthetic } \\
\text { Thymosin } \beta 4\end{array}$ & $\begin{array}{l}\text { acute } \\
\text { myocardial } \\
\text { infarction }\end{array}$ & $\begin{array}{l}\text { patients with acute } \\
\text { myocardial infarction }\end{array}$ & Not report & $\begin{array}{l}\text { T } \beta 4 \text { could protect and repair the heart } \\
\text { and reduce the volume of scars after } \\
\text { heart attack. }\end{array}$ & completed & $(71)$ \\
\hline II & $\begin{array}{l}\text { chemosynthetic } \\
\text { Thymosin } \beta 4\end{array}$ & $\begin{array}{l}\text { congenital } \\
\text { heart surgery }\end{array}$ & $\begin{array}{l}12 \text { children up to four } \\
\text { months of age }\end{array}$ & $\begin{array}{l}\text { T } \beta 4 \text { at } 5 \text { mg/kg/dose, } 12.5 \\
\mathrm{mg} / \mathrm{kg} / \mathrm{dose} \text {, and } \\
20 \mathrm{mg} / \mathrm{kg} / \mathrm{dose} \text {, } \\
\text { intravenous injections, and } \\
\text { given in the operating room } \\
\text { 15-30 minutes before } \\
\text { cardiopulmonary bypass }\end{array}$ & $\begin{array}{l}\text { T } \beta 4 \text { could improve ischemia-reperfusion } \\
\text { injury during congenital heart surgery. }\end{array}$ & completed & $(72)$ \\
\hline II & $\begin{array}{l}\text { RGN-259 } \\
\text { (Thymosin } \beta 4 \text { ) }\end{array}$ & dry eye & $\begin{array}{l}9 \text { patients with severe } \\
\text { dry eye }\end{array}$ & $\begin{array}{l}\text { Each } 8 \mathrm{~mL} \text { plastic squeeze } \\
\text { bottle contained } 2.0 \mathrm{~mL} \text { fill } \\
\text { volume }\end{array}$ & $\begin{array}{l}\text { Tß4 could tear increase film breakup } \\
\text { time and tear volume production. }\end{array}$ & completed & (88) \\
\hline II & $\begin{array}{l}\text { chemosynthetic } \\
\text { Thymosin } \beta 4\end{array}$ & $\begin{array}{l}\text { epidermolysis } \\
\text { bullosa }\end{array}$ & $\begin{array}{l}\text { Approximately } 35-40 \\
\text { patients with RDEB or } \\
\text { JEB, aged } 2 \text { or above }\end{array}$ & Not report & $\begin{array}{l}\text { Although as yet unproven, topically } \\
\text { applied T } \beta 4 \text { may prove to be an } \\
\text { extremely important addition to the } \\
\text { overall management of patients with this } \\
\text { potentially devastating disease. }\end{array}$ & Recruiting & $(103)$ \\
\hline II & $\begin{array}{l}\text { Thymosin } \beta 4 \\
\text { Gel }\end{array}$ & $\begin{array}{l}\text { stasis and } \\
\text { pressure } \\
\text { ulcers }\end{array}$ & $\begin{array}{l}143 \text { total patients with } \\
\text { chronic cutaneous (stage } \\
\text { III/IV) pressure ulcers (full } \\
\text { thickness) and venous } \\
\text { stasis ulcers }\end{array}$ & $\begin{array}{l}0.01 \%, 0.03 \% \text {, or } 0.1 \% \\
T \beta 4 \text { in the gel formulation }\end{array}$ & $\begin{array}{l}\text { T } \beta 4 \text { could accelerate healing by almost } \\
\text { a month in those patients that did heal. }\end{array}$ & completed & (104) \\
\hline II & $\begin{array}{l}\text { Thymosin } \beta 4 \\
\text { Gel }\end{array}$ & $\begin{array}{l}\text { venous stasis } \\
\text { ulcers }\end{array}$ & 73 patients & $\begin{array}{l}0.01 \%, 0.03 \% \text {, or } 0.1 \% \\
\text { T } \beta 4 \text { in the gel formulation } \\
\text { and treated for } 84 \text { days }\end{array}$ & $\begin{array}{l}\text { T } \beta 4 \text { could accelerate wound healing } \\
\text { and that complete wound healing can be } \\
\text { achieved within } 3 \text { months in about } 25 \% \\
\text { of the patients. }\end{array}$ & completed & $(105)$ \\
\hline
\end{tabular}

effective in treating gastrointestinal disorders (121). In a mouse colitis model resembling Crohn's disease, AAV-T $\beta 4$-treated mice displayed distinctly attenuated colon injuries and reduced the apoptosis rates in colonic mucosal epithelia. AAV-T $\beta 4$ significantly reduced inflammatory cell infiltration and alleviated oxidative stress in the inflamed colons of mice, as evidenced by decreased myeloperoxidase activity and malondialdehyde levels and increased superoxide dismutase activity. AAV-T $\beta 4$ further modulated colonic TNF- $\alpha$, IL-1 $\beta$, and IL-10 levels and suppressed the compensatory proliferation of colonic epithelial cells (122).

In addition, $\mathrm{T} \beta 4$ exerts a therapeutic effect on colon cancer. The expression of T $\beta 4$ in rectal cancer stem cells was higher than that in normal epithelial cells. Lentivirus was used to reduce levels of $\mathrm{T} \beta 4$ in rectal cancer stem cells, and interestingly, this treatment reduced the tumor size and aggressiveness of colorectal cancer stem cell-based xenografts in mice (123).

\section{Tß4 Alleviates Inflammation}

$\mathrm{T} \beta 4$ exhibits anti-inflammatory activities in different pathologies (124) and reduces inflammation in the brain (26), liver (27), eye (89), and heart diseases (80). Diverse mechanisms underlying the inflammatory response via $\mathrm{T} \beta 4$ regulation following injuries are observed (125). NF- $\kappa \mathrm{B}$ regulates the expression of various inflammatory genes and is crucial in the inflammatory process (126). T $\beta 4$ can downregulate NF- $\kappa B$ (127) and reduce levels of numerous inflammatory cytokines such as TNF- $\alpha$ (128). It can also prevent the activation of $\mathrm{NF}-\kappa \mathrm{B}$ by blocking the phosphorylation of the inhibitory protein $\mathrm{I} \kappa \mathrm{B}$, thereby inhibiting proinflammatory cytokine production (31). Sosne et al. demonstrated that in human epithelial corneal cells stimulated with TNF- $\alpha$, T $\beta 4$ significantly decreased NF- $\kappa B$ activation, p65 subunit phosphorylation, and nuclear translocation (127). Ping et al. reported that $\mathrm{T} \beta 4$ could inhibit TNF- $\alpha$-induced NF- $\kappa \mathrm{B}$ activation and block RelA/p65 
translocation and the sensitizing effects of its intracellular binding partners PINCH-1 and integrin-linked kinase (128). Furthermore, some studies have provided preliminary evidence on the ability of T $\beta 4$ to resolve inflammation by promoting noncanonical autophagy associated with the activation of the DAP kinase anti-inflammatory function (129-132).

In summary, $\mathrm{T} \beta 4$ exerts therapeutic effects on various injuries or diseases of different tissues, while the underlying mechanisms have some similarities and differences (Tables 1 and 2).

\section{CONCLUSION AND FUTURE PERSPECTIVES}

$\mathrm{T} \beta 4$ is a natural endogenous repair factor that is activated during development and tissue damage. This peptide exerts various biological activities, such as inhibition of inflammation and apoptosis as well as promotion of proliferation and angiogenesis. Moreover, animal experiments and clinical studies have reported that T $\beta 4$ exerts therapeutic effects on several diseases or injuries, such as myocardial infarction and myocardial ischemia-reperfusion injury, xerophthalmia, liver and renal fibrosis, ulcerative colitis and colon cancer, and skin trauma. The regulation of $\mathrm{T} \beta 4$ in some signaling pathways, including the PI3K/Akt/eNOS pathway, Notch pathway, TGF $\beta /$ smad pathway, Wnt pathway, and apoptosis pathway, might serve as the underlying mechanisms of its effects.

Judging from the updated literature outlined in this review, there is burgeoning interest in the functions and applications of $\mathrm{T} \beta 4$. It could be speculated that $\mathrm{T} \beta 4$ might be a safe and efficacious new drug for various clinical indications in the near future.

\section{REFERENCES}

1. Zisblatt M, Goldstein AL, Lilly F, White A. Acceleration by Thymosin of the Development of Resistance to Murine Sarcoma Virus-Induced Tumor in Mice. Proc Natl Acad Sci USA (1970) 66:1170-4. doi: 10.1073/pnas.66.4.1170

2. Huff T, Müller CS, Otto AM, Netzker R, Hannappel E. Beta-Thymosins, Small Acidic Peptides With Multiple Functions. Int J Biochem Cell Biol (2001) 33:205-20. doi: 10.1016/S1357-2725(00)00087-X

3. Hannappel E, Huff T. The Thymosins. Prothymosin Alpha, Parathymosin, and Beta-Thymosins: Structure and Function. Vitam Horm (2003) 66:25796. doi: 10.1016/S0083-6729(03)01007-0

4. Goldstein AL, Hannappel E, Kleinman HK. Thymosin B4: ActinSequestering Protein Moonlights to Repair Injured Tissues. Trends Mol Med (2005) 11:421-9. doi: 10.1016/j.molmed.2005.07.004

5. Goldstein AL, Slater FD, White A. Preparation, Assay, and Partial Purification of a Thymic Lymphocytopoietic Factor (Thymosin). Proc Natl Acad Sci USA (1966) 56:1010-7. doi: 10.1073/pnas.56.3.1010

6. Sosne G, Christopherson PL, Barrett RP, Fridman R. Thymosin- $\beta 4$ Modulates Corneal Matrix Metalloproteinase Levels and Polymorphonuclear Cell Infiltration After Alkali Injury. Invest Ophthalmol Vis Sci (2005) 46:2388-95. doi: 10.1167/iovs.04-1368

7. Hannappel E, Xu GJ, Morgan J, Hempstead J, Horecker BL. Thymosin Beta 4: A Ubiquitous Peptide in Rat and Mouse Tissues. Proc Natl Acad Sci USA (1982) 79:2172-5. doi: 10.1073/pnas.79.7.2172

8. Smart N, Risebro CA, Melville AA, Moses K, Schwartz RJ, Chien KR, et al. Thymosin $\beta 4$ Induces Adult Epicardial Progenitor Mobilization and Neovascularization. Nature (2007) 445:177-82. doi: 10.1038/nature05383
However, the remarkable progress in both basic research and clinical trials has also raised new questions, such as thorough elucidation of the mechanisms of some applications, and exploration of more promising indications. The upstream and downstream components regulate $\mathrm{T} \beta 4$ functions need to be thoroughly delineated, especially the upstream regulation mechanism. Moreover, the crosstalk of the downstream signaling pathways of $\mathrm{T} \beta 4$ should be further clarified. Furthermore, some functions of T $\beta 4$, such as the inhibition of inflammation and apoptosis as well as promotion of proliferation and angiogenesis, should be explored furtherly to find new clinical indications. Currently, our group and others are conducting preclinical studies to demonstrate the efficacy of $\mathrm{T} \beta 4$ in various animal models, with the goal of pushing new indications into clinical trials. In addition, new technologies in pharmacy, pharmaceutics and material science should be used to promote the application of $\mathrm{T} \beta 4$ in different indications in a more appropriate dosage form.

\section{AUTHOR CONTRIBUTIONS}

All authors contributed to draft and revise the article, gave final approval of the version to be published, and agreed to be accountable for all aspects of the work.

\section{FUNDING}

This study was supported by the funds from Major national science and technology projects (Grant No. 2018ZX09J18103-006).
9. Wang D, Carretero OA, Yang XY, Rhaleb NE, Liu YH, Liao TD, et al. NAcetyl-Seryl-Aspartyl-Lysyl-Proline Stimulates Angiogenesis In Vitro and In Vivo. Am J Physiol Heart Circ Physiol (2004) 287:2099-105. doi: 10.1152/ ajpheart.00592.2004

10. Malinda KM, Goldstein AL, Kleinman HK. Thymosin Beta 4 Stimulates Directional Migration of Human Umbilical Vein Endothelial Cells. FASEB J (1997) 11:474-81. doi: 10.1096/fasebj.11.6.9194528

11. Krenning G, Zeisberg EM, Kalluri R. The Origin of Fibroblasts and Mechanism of Cardiac Fibrosis. J Cell Physiol (2010) 225(3):631-7. doi: 10.1002/jcp.22322

12. Espira L, Czubryt MP. Emerging Concepts in Cardiac Matrix Biology. Can J Physiol Pharmacol (2009) 87:996-1008. doi: 10.1139/Y09-105

13. Quan Z, Wang QL, Zhou P, Wang GD, Tan YZ, Wang HJ. Thymosin Beta 4 Promotes the Survival and Angiogenesis of Transplanted Endothelial Progenitor Cells in the Infarcted Myocardium. Int J Mol Med (2017) 39:1347-56. doi: 10.3892/ijmm.2017.2950

14. Zhao Y, Zhao Y, Song J, Gao J, Shen Z, Zhu J, et al. Thymosin $\beta 4$ Promotes Endothelial Progenitor Cell Angiogenesis via a Vascular Endothelial Growth Factordependent Mechanism. Mol Med Rep (2018) 18:2314-20. doi: $10.3892 / \mathrm{mmr} .2018 .9199$

15. Kim JH, Lim IR, Park CY, Joo HJ, Noh JM, Choi SC, et al. Thymosin $\beta 4$ Enhancing Therapeutic Efficacy of Human Adipose-Derived Stem Cells in Mouse Ischemic Hindlimb Model. Int J Mol Sci (2020) 21:2166. doi: 10.3390/ ijms21062166

16. Chao TC, Chen KJ, Tang MC, Chan LC, Chen PM, Tzeng CH, et al. Thymosin Beta-4 Knockdown in IEC-6 Normal Intestinal Epithelial Cells Induces DNA Re-Replication via Downregulating Emil. J Cell Physiol (2014) 229:1639-46. doi: 10.1002/jcp.24609 
17. Kim DH, Moon EY, Yi JH, Lee HE, Park SJ, Ryu YK, et al. Peptide Fragment of Thymosin $\beta 4$ Increases Hippocampal Neurogenesis and Facilitates Spatial Memory. Neuroscience (2015) 310:51-62. doi: 10.1016/j.neuroscience.2015.09.017

18. Jeon BJ, Yang Y, Kyung Shim S, Yang HM, Cho D, Ik Bang S. Thymosin Beta-4 Promotes Mesenchymal Stem Cell Proliferation via an Interleukin-8Dependent Mechanism. Exp Cell Res (2013) 319:2526-34. doi: 10.1016/ j.yexcr.2013.04.014

19. Zhang J, Zhang ZG, Li Y, Lu M, Zhang Y, Elias SB, et al. Thymosin Beta4 Promotes Oligodendrogenesis in the Demyelinating Central Nervous System. Neurobiol Dis (2016) 88:85-95. doi: 10.1016/j.nbd.2016.01.010

20. Chen S, Shimoda M, Chen J, Grayburn PA. Stimulation of Adult Resident Cardiac Progenitor Cells by Durable Myocardial Expression of Thymosin Beta 4 With Ultrasound-Targeted Microbubble Delivery. Gene Ther (2013) 20:225-33. doi: 10.1038/gt.2012.89

21. Hao Q, He L, Zhou J, Yuan Y, Ma X, Pang Z, et al. A Dimeric Thymosin Beta 4 With Novel Bio-Activity Protects Post-Ischemic Cardiac Function by Accelerating Vascular Endothelial Cell Proliferation. Int J Cardiol (2018) 261:146-54. doi: 10.1016/j.ijcard.2018.03.052

22. Yuan J, Shen Y, Yang X, Xie Y, Lin X, Zeng W, et al. Thymosin $\beta 4$ Alleviates Renal Fibrosis and Tubular Cell Apoptosis Through TGF- $\beta$ Pathway Inhibition in UUO Rat Models. BMC Nephrol (2017) 18:314. doi: 10.1186/ s12882-017-0708-1

23. Wang YY, Zhu QS, Wang YW, Yin RF. Thymosin Beta-4 Recombinant Adeno-Associated Virus Enhances Human Nucleus Pulposus Cell Proliferation and Reduces Cell Apoptosis and Senescence. Chin Med J (2015) 128:1529-35. doi: 10.4103/0366-6999.157686

24. Zhao Y, Qiu F, Xu S, Yu L, Fu G. Thymosin $\beta 4$ Activates Integrin-Linked Kinase and Decreases Endothelial Progenitor Cells Apoptosis Under Serum Deprivation. J Cell Physiol (2011) 226:2798-806. doi: 10.1002/jcp.22624

25. Niu M, Nachmias VT. Increased Resistance to Apoptosis in Cells Overexpressing Thymosin Beta Four: A Role for Focal Adhesion Kinase Pp125fak. Cell Adhes Commun (2000) 7:311-20. doi: 10.3109/ 15419060009015002

26. Zhang Z, Liu S, Huang S. Effects of Thymosin $\beta 4$ on Neuronal Apoptosis in a Rat Model of Cerebral Ischemiareperfusion Injury. Mol Med Rep (2019) 20:4186-92. doi: 10.3892/mmr.2019.10683

27. Zhang Z, Liu S, Huang S. Thymosin $\beta 4$ Prevents Oxygen-Glucose Deprivation/Reperfusion-Induced Injury in Rat Cortical Neurons. Neuropsychiatr Dis Treat (2019) 15:2385-93. doi: 10.2147/NDT.S208600

28. Ji $\mathrm{H}, \mathrm{Xu} \mathrm{L}$, Wang $\mathrm{Z}$, et al. Effects of Thymosin $\beta 4$ on Oxygen-Glucose Deprivation and Reoxygenation-Induced Injury. Int J Mol Med (2018) 41:1749-55. doi: 10.3892/ijmm.2018.3369

29. Santra M, Chopp M, Santra S, Nallani A, Vyas S, Zhang ZG, et al. Thymosin Beta 4 Up-Regulates miR-200a Expression and Induces Differentiation and Survival of Rat Brain Progenitor Cells. J Neurochem (2016) 136:118-32. doi: $10.1111 /$ jnc. 13394

30. Zhang J, Zhang ZG, Morris D, Li Y, Roberts C, Elias SB, et al. Neurological Functional Recovery After Thymosin Beta4 Treatment in Mice With Experimental Auto Encephalomyelitis. Neuroscience (2009) 164:1887-93. doi: 10.1016/j.neuroscience.2009.09.054

31. Shah R, Reyes-Gordillo K, Cheng Y, Varatharajalu R, Ibrahim J, Lakshman MR. Thymosin $\beta 4$ Prevents Oxidative Stress, Inflammation, and Fibrosis in Ethanol- and LPS-Induced Liver Injury in Mice. Oxid Med Cell Longev (2018) 2018:1-12. doi: 10.1155/2018/9630175

32. Zhang J, Wu J, Zeng W, Yao K, Zu H, Zhao Y. Function of Thymosin Beta-4 in Ethanol-Induced Microglial Activation. Cell Physiol Biochem (2016) 38:2230-8. doi: 10.1159/000445578

33. Zhou L, Gao XP, Mei-Lun H. Effect of P13k/Akt Signaling Pathway on the Biological Behaviors of Brain Microvessel Endothelial Cells. Chin J Modern Med (2010) 15:2272-2.

34. Manning BD, Cantley LC. AKT/PKB Signaling: Navigating Downstream. Cell (2007) 129:1261-74. doi: 10.1016/j.cell.2007.06.009

35. Petit I, Jin D, Rafii S. The SDF-1-CXCR4 Signaling Pathway: A Molecular Hub Modulating Neo-Angiogenesis. Trends Immunol (2007) 28:299-307. doi: 10.1016/j.it.2007.05.007

36. Qiu FY. Effect of Thymosin $\beta 4$ on Peripheral Blood Endothelial Progenitor Cell Function and its Mechanism. Zhejiang: School of Medicine, Zhejiang University (2019).
37. Pang YS. Effect and Mechanism of Thymosin $\beta 4$ on Angiogenesis After Focal Cerebral Ischemia Reperfusion in Rats. Chongqing: Chongqing Medical University (2010).

38. Trenkwalder T, Deindl E, Bongiovanni D, Lee S, Schunkert H, Kupatt C, et al. Thymosin- $\beta 4$-Mediated Therapeutic Neovascularization: Role of the PI3K/AKT Pathway. Expert Opin Biol Ther (2015) 15:175-85. doi: 10.1517/ 14712598.2015.1011122

39. Hinkel R, Ball HL, Dimaio JM, Shrivastava S, Thatcher JE, Singh AN, et al. C-Terminal Variable AGES Domain of Thymosin $\beta 4$ : The Molecule's Primary Contribution in Support of Post-Ischemic Cardiac Function and Repair. J Mol Cell Cardiol (2015) 87:113-25. doi: 10.1016/j.yjmcc. 2015.07.004

40. Ehebauer M, Hayward P, Arias AM. Notch, a Universal Arbiter of Cell Fate Decisions. Science (2006) 314:1414-5. doi: 10.1126/science.1134042

41. Luttun A, Carmeliet G, Carmeliet P. Vascular Progenitors: From Biology to Treatment. Trends Cardiovasc Med (2002) 12:88-96. doi: 10.1016/S1050$1738(01) 00152-9$

42. Lv S, Cheng G, Zhou Y, Xu G. Thymosin Beta4 Induces Angiogenesis Through Notch Signaling in Endothelial Cells. Mol Cell Biochem (2013) 381:283-90. doi: 10.1007/s11010-013-1713-8

43. Lv S, Cai H, Xu Y, Dai J, Rong X, Zheng L. Thymosin $\beta 4$ Induces Angiogenesis in Critical Limb Ischemia Mice via Regulating Notch/Nfikb Pathway. Int J Mol Med (2020) 46:1347-58. doi: 10.3892/ijmm.2020.4701

44. Takeshita K, Satoh M, Ii M, Silver M, Limbourg FP, Mukai Y, et al. Critical Role of Endothelial Notch1 Signaling in Postnatal Angiogenesis. Circ Res (2007) 100:70-8. doi: 10.1161/01.RES.0000254788.47304.6e

45. Kikuchi R, Takeshita K, Uchida Y, Kondo M, Cheng XW, Nakayama T, et al. Pitavastatin-Induced Angiogenesis and Arteriogenesis is Mediated by Notch1 in a Murine Hindlimb Ischemia Model Without Induction of VEGF. Lab Invest (2011) 91:691-703. doi: 10.1038/labinvest.2011.5

46. Jin Y, Kaluza D, Jakobsson L. VEGF, Notch and Tgf $/$ BMPs in Regulation of Sprouting Angiogenesis and Vascular Patterning. Biochem Soc Trans (2014) 42:1576-83. doi: 10.1042/BST20140231

47. Caporarello N, Lupo G, Olivieri M, Classical VEGF. Notch and Ang Signalling in Cancer Angiogenesis, Alternative Approaches and Future Directions (Review). Mol Med Rep (2017) 16:4393-402. doi: 10.3892/ mmr.2017.7179

48. Lin CL, Wang FS, Hsu YC, Chen CN, Tseng MJ, Saleem MA, et al. Modulation of Notch-1 Signaling Alleviates Vascular Endothelial Growth Factor-Mediated Diabetic Nephropathy. Diabetes (2010) 59:1915-25. doi $10.2337 / \mathrm{db} 09-0663$

49. Fabregat I, Caballero-Diaz D. Transforming Growth Factor-Beta-Induced Cell Plasticity in Liver Fibrosis and Hepatocarcinogenesis. Front Oncol (2018) 8:357. doi: 10.3389/fonc.2018.00357

50. Xu F, Liu C, Zhou D, Zhang L. TGF-Beta/SMAD Pathway and its Regulation in Hepatic Fibrosis. J Histochem Cytochem (2016) 64:157-67. doi: 10.1369/ 0022155415627681

51. Chen C, Li X, Wang L. Thymosin $\beta 4$ Alleviates Cholestatic Liver Fibrosis in Mice Through Downregulating PDGF/PDGFR and Tgf $/$ /Smad Pathways. Dig Liver Dis (2020) 52:324-30. doi: 10.1016/j.dld.2019.08.014

52. Zhang Y, Zhang ZG, Chopp M, Meng Y, Zhang L, Mahmood A, et al. Treatment of Traumatic Brain Injury in Rats With N-Acetyl-Seryl-Aspartyl-Lysyl-Proline. J Neurosurg (2017) 126:782-95. doi: 10.3171/2016.3.JNS152699

53. Huelsken J, Vogel R, Erdmann B, Cotsarelis G, Birchmeier W. $\beta$-Catenin Controls Hair Follicle Morphogenesis and Stem Cell Differentiation in the Skin. Cell (2001) 105:533-45. doi: 10.1016/S0092-8674(01)00336-1

54. Hsieh CH, Cheng LH, Hsu HH, Ho TJ, Tu CC, Lin YM, et al. ApicidinResistant HA22T Hepatocellular Carcinoma Cells Strongly Activated the Wnt/betacatenin Signaling Pathway and MMP-2 Expression via the IGFIR/ PI3K/Akt Signaling Pathway Enhancing Cell Metastatic Effect. Biosci Biotechnol Biochem (2013) 77:2397-404. doi: 10.1271/bbb.130503

55. Fuchs E, Raghavan S. Getting Under the Skin of Epidermal Morphogenesis. Nat Rev Genet (2002) 3:199-209. doi: 10.1038/nrg758

56. Gao XY, Hou F, Zhang ZP, Nuo MT, Liang H, Cang M, et al. Role of Thymosin Beta 4 in Hair Growth. Mol Genet Genomics (2016) 291:1639-46. doi: 10.1007/s00438-016-1207-y

57. Wang LC, Liu ZY, Gambardella L, Delacour A, Shapiro R, Yang J, et al. Conditional Disruption of Hedgehog Signaling Pathway Defines Its Critical 
Role in Hair Development and Regeneration. J Invest Dermatol (2000) 114:901-8. doi: 10.1046/j.1523-1747.2000.00951.x

58. Li Y, Bao X, Chen X. Thymosin Beta4 Increases Mouse Hair Regeneration. Chin J Tissue Eng Res (2014) 18:1687-93. doi: 10.3969/j.issn.20954344.2014.11.008

59. Lin G, Chen Y, Slack JMW. Imparting Regenerative Capacity to Limbs by Progenitor Cell Transplantation. Dev Cell (2013) 24:41-51. doi: 10.1016/ j.devcel.2012.11.017

60. Gupta S, Li L. The Role of Thymosin $\beta 4$ in Angiotensin II-Induced Cardiomyocytes Growth. Expert Opin Biol Ther (2018) 18:105-10. doi: 10.1080/14712598.2018.1494718

61. Cory S, Adams JM. The Bcl2 Family: Regulators of the Cellular Life-orDeath Switch. Nat Rev Cancer (2002) 2:647-56. doi: 10.1038/nrc883

62. Zhu Z, Zhang Y, Huang X, Can L, Zhao X, Wang Y, et al. Thymosin Beta 4 Alleviates Non-Alcoholic Fatty Liver by Inhibiting Ferroptosis via UpRegulation of GPX4. Eur J Pharmacol (2021) 908:174351. doi: 10.1016/ j.ejphar.2021.174351

63. Sosne G, Siddiqi A, Kurpakus-Wheater M. Thymosin-Beta4 Inhibits Corneal Epithelial Cell Apoptosis After Ethanol Exposure In Vitro. Invest Ophthalmol Vis Sci (2004) 45:1095-100. doi: 10.1167/iovs.03-1002

64. Ho JH, Chuang CH, Ho CY, Shih YR, Lee OK, Su Y. Internalization is Essential for the Antiapoptotic Effects of Exogenous Thymosin Beta-4 on Human Corneal Epithelial Cells. Invest Ophthalmol Vis Sci (2007) 48:27-33. doi: 10.1167/iovs.06-0826

65. Iguchi K, Usami Y, Hirano K, Hamatake M, Shibata M, Ishida R, et al. Decreased Thymosin Beta4 in Apoptosis Induced by a Variety of Antitumor Drugs. Biochem Pharmacol (1999) 57:1105-11. doi: 10.1016/S0006-2952(99) 00030-1

66. Lu L, Liu M, Sun R, Zheng Y, Zhang P. Myocardial Infarction: Symptoms and Treatments. Cell Biochem Biophys (2015) 72:865-7. doi: 10.1007/ s12013-015-0553-4

67. Wang N, Liu C, Wang X, He T, Li L, Liang X, et al. Hyaluronic Acid Oligosaccharides Improve Myocardial Function Reconstruction and Angiogenesis Against Myocardial Infarction by Regulation of Macrophages. Theranostics (2019) 9(7):1980-92. doi: 10.7150/thno. 31073.18810728

68. Bao W, Ballard VL, Needle S, Hoang B, Lenhard SC, Tunstead JR, et al. Cardioprotection by Systemic Dosing of Thymosin Beta Four Following Ischemic Myocardial Injury. Front Pharmacol (2013) 4:149. doi: 10.3389/ fphar.2013.00149

69. Wang X, Liu L, Qi L, Lei C, Li P, Wang Y, et al. A First-in-Human, Randomized, Double-Blind, Single- and Multiple-Dose, Phase I Study of Recombinant Human Thymosin $\beta 4$ in Healthy Chinese Volunteers. J Cell Mol Med (2021) 25:8222-8. doi: 10.1111/jcmm.16693

70. Ruff D, Crockford D, Girardi G, Zhang Y. A Randomized, PlaceboControlled, Single and Multiple Dose Study of Intravenous Thymosin Beta4 in Healthy Volunteers. Ann N Y Acad Sci (2010) 1194:223-9. doi: 10.1111/j.1749-6632.2010.05474.x

71. Goldstein AL, Hannappel E, Sosne G, Kleinman HK. Thymosin $\beta 4$ : A MultiFunctional Regenerative Peptide. Basic Properties and Clinical Applications. Expert Opin Biol Ther (2012) 12:37-51. doi: 10.1517/14712598.2012.634793

72. Stromberg, RS, Raymond T, Samuel D, Crockford D, Stigall W, Leonard S, et al. Use of the Cardioprotectants Thymosin Beta 4 and Dexrazoxane During Congenital Heart Surgery: Proposal for a Randomized, DoubleBlind, Clinical Trial. Ann N Y Acad Sci (2012) 1270:59-65. doi: 10.1111/ j.1749-6632.2012.06710.x

73. Postrach J, Schmidt M, Thormann M, Thein E, Burdorf L, Reichart B, et al. Adeno-Associated Viral Vector 2.9 Thymosin 4 Application Attenuates Rejection After Heart Transplantation: Results of a Preclinical Study in the Pig. Transplantation (2014) 98:835-43. doi: 10.1097/TP.0000000000000327

74. Ye L, Zhang P, Duval S, Su L, Xiong Q, Zhang J. Thymosin $\beta 4$ Increases the Potency of Transplanted Mesenchymal Stem Cells for Myocardial Repair. Circulation (2013) 128:32-41. doi: 10.1161/CIRCULATIONAHA. 112.000025

75. Rui L, Yu N, Hong L, Feng H, Chunyong H, Jian M, et al. Extending the Time Window of Mammalian Heart Regeneration by Thymosin Beta 4 . J Cell Mol Med (2014) 18:2417-24. doi: 10.1111/jcmm.12421
76. Leistner DM, Fischer-Rasokat U, Honold J, Seeger FH, Schächinger V, Lehmann R, et al. Transplantation of Progenitor Cells and Regeneration Enhancement in Acute Myocardial Infarction: Final One-Year Results of the TOPCARE-AMI Trial. Clin Res Cardiol (2004) 100:925-34. doi: 10.1007/ s00392-011-0327-y

77. Aicher A, Brenner W, Zuhayra M, Badorff C, Massoudi S, Assmus B, et al. Assessment of the Tissue Distribution of Transplanted Human Endothelial Progenitor Cells by Radioactive Labeling. Circulation (2003) 107:2134-9. doi: 10.1161/01.CIR.0000062649.63838.C9

78. Zhu J, Song J, Yu L, Zheng H, Zhou B, Weng S, et al. Safety and Efficacy of Autologous Thymosin $\beta 4$ Pre-Treated Endothelial Progenitor Cell Transplantation in Patients With Acute ST Segment Elevation Myocardial Infarction: A Pilot Study. Cytotherapy (2016) 18:1037-42. doi: 10.1016/ j.jcyt.2016.05.006

79. Gupta S, Kumar S, Sopko N, Qin Y, Wei C, Kim IK. Thymosin $\beta 4$ and Cardiac Protection: Implication in Inflammation and Fibrosis. Ann N Y Acad Sci (2012) 1269:84-91. doi: 10.1111/j.1749-6632.2012.06752.x

80. Marks ED, Kumar A. Thymosin Beta4: Roles in Development, Repair, and Engineering of the Cardiovascular System. Vitam Horm (2016) 102:227-49. doi: 10.1016/bs.vh.2016.04.010

81. Bock-Marquette I, Saxena A, White MD, Dimaio JM, Srivastava D. Thymosin Beta4 Activates Integrin-Linked Kinase and Promotes Cardiac Cell Migration, Survival and Cardiac Repair. Nature (2004) 432:466-72. doi: 10.1038/nature 03000

82. Long A. Thymosin $\beta 4$ Promote the Wound Healing of Cornea. Rec Adv Ophthalmol (2010) 06:597-600.

83. Sosne G, Qiu P, Kurpakus-Wheater M, Matthew H. Thymosin Beta4 and Corneal Wound Healing: Visions of the Future. Ann N Y Acad Sci (2010) 1194:190-8. doi: 10.1111/j.1749-6632.2010.05472.x

84. Sosne G, Christopherson PL, Barrett RP, Fridman R. Thymosin-IU03b24 Modulates Corneal Matrix Metalloproteinase Levels and Polymorphonuclear Cell Infiltration After Alkali Injury. Invest Ophthalmol Vis Sci (2005) 46:2388-95. doi: 10.1167/iovs.04-1368

85. Long AH. Expression of MMP-2 and TIMP-2 Regulated by Recombinant Thymosine $\beta 4$ After Corneal Alkali Burn in Rabbits. Rec Adv Ophthalmol (2010) 30:723-6.

86. Liu JH, Hao M, Li X. Inhibitory Effects of Thymosin $\beta 4$ on H2O2- Induced Oxidative Damage and Subsequent Cell Apoptosis of Rabbit Corneal Keratocytes. Rec Adv Ophthalmol (2019) 273:13-8. doi: 10.13389/ j.cnki.rao.2019.0047

87. Sosne G, Qiu P, Ousler GW, Dunn SP, Crockford D. Thymosin $\beta 4$ : A Potential Novel Dry Eye Therapy. Ann N Y Acad Sci (2012) 1270:45-50. doi: 10.1111/j.1749-6632.2012.06682.x

88. Sosne G, Dunn SP, Kim C. Thymosin $\beta 4$ Significantly Improves Signs and Symptoms of Severe Dry Eye in a Phase 2 Randomized Trial. Cornea (2015) 34:491-6. doi: 10.1097/ICO.0000000000000379

89. Jin R, Li Y, Li L, Kim DH, Yang CD, Son HS, et al. Antiinflammatory Effects of Glycine Thymosin $\beta 4$ Eye Drops in Experimental Dry Eye. BioMed Rep (2020) 12:319-25. doi: 10.3892/br.2020.1296

90. Luo L, Reinach PS, Kao WY. Corneal Epithelial Wound Healing. Exp Biol Med (2001) 226:653-64. doi: 10.1177/153537020222600711

91. Li Y. Recombinant Thymosin Beta 4 Accelerates Skin Wound Healing by Regulating Vascular Endothelial Growth Factor and Basic Fibroblast Growth Factor Expression. J Cli Rehab Tissue Eng Res (2008) 12:9857-986.

92. Treadwell T, Kleinman HK, Crockford D, Hardy MA, Guarnera GT, Goldstein AL. The Regenerative Peptide Thymosin $\beta 4$ Accelerates the Rate of Dermal Healing in Preclinical Animal Models and in Patients. Ann N Y Acad Sci (2012) 1270:1306-10. doi: 10.1111/j.17496632.2012.06717.x

93. Kleinman H, Sosne G. Thymosin Beta 4 Promotes Dermal Healing. Vit Horm (2016) 102:251-75. doi: 10.1016/bs.vh.2016.04.005

94. Smart N, Riseboro CA, Melville AA, Moses K, Schwartz RJ, Chien KR, et al. Thymosin Beta 4 Induces Adult Cardiac Progenitor Mobilization and Neovascularization. Nature (2007) 44:177-82. doi: 10.1038/nature05383

95. Bollini S, Riley PR, Smart N. Thymosin Beta 4: Multiple Functions in Protection, Repair, and Regeneration of the Mammalian Heart. Expert Opin Biol Ther (2015) 22:1-12. doi: 10.1517/14712598.2015.1022526 
96. Roy P, Raifur Z, Jones D. Local Photorelease of Caged Thymosin Beta 4 in Locomoting Keratocytes Causes Cell Turning. J Cell Biol (2001) 153:103548. doi: $10.1083 /$ jcb.153.5.1035

97. Lin Y, Lin B, Lin D, Huang G, Cao B. Effect of Thymosin $\beta 4$ on the Survival of Random Skin Flaps in Rats. J Reconstr Microsurg (2015) 31:464-70. doi: 10.1055/s-0035-1549444

98. Yu H. Thymosin $\beta 4$ Regulates the Expression of VEGF and Laminin-5 in Accelerating Skin Wound Healing in Diabetic Rat. Chin J Diabetes (2011) 19:60. doi: 10.1002/term.2028

99. Kim S, Kwon J. Thymosin $\beta 4$ has a Major Role in Dermal Burn Wound Healing That Involves Actin Cytoskeletal Remodelling via Heat-Shock Protein 70. J Tissue Eng Regener Med (2017) 11:1262-73. doi: 10.1002/ term. 2028

100. Fan Y, Gong Y, Ghosh PK, Graham LM, Fox PL. Spacial Coordination of Actin Polymerization and ILK-Akt2 Activity During Endothelial Cell Migration. Dev Cell (2009) 16:661-74. doi: 10.1016/j.devcel.2009.03.009

101. Sosne G, Xu L, Prach L, Mrock LK, Kleinman HK, Letterio JJ, et al. Thymosin Beta 4 Stimulates Laminin- 5 Production Independent of TGF-Beta. Exp Cell Res (2004) 293:175-83. doi: 10.1016/j.yexcr.2003.09.022

102. Goldstein AL, Hannappel E, Sosne G, Kleinman HK. Thymosin Beta 4: A Multi-Functional Regenerative Peptide. Basic properties and clinical applications. Expert Opin Biol Ther (2012) 12:37-51. doi: 10.1517/ 14712598.2012.634793

103. Fine JD. Epidermolysis Bullosa: A Genetic Disease of Altered Cell Adhesion and Wound Healing, and the Possible Clinical Utility of Topically Applied Thymosin Beta4. Ann N Y Acad (2007) 1112:396-406. doi: 10.1196/ annals. 1415.017

104. Treadwell T, Kleinman HK, Crockford D, Hardy MA, Guarnera GT, Goldstein AL. The Regenerative Peptide Thymosin $\beta 4$ Accelerates the Rate of Dermal Healing in Preclinical Animal Models and in Patients. Ann N Y Acad Sci (2012) 1270:37-44. doi: 10.1111/j.1749-6632.2012.06717.x

105. Guarnera G, Derosa A, Camerini R. The Effect of Thymosin Treatment of Venous Ulcers. Ann N Y Acad Sci (2010) 1194:207-12. doi: 10.1111/j.17496632.2010.05490.x

106. Lu X. Protective Effect of Thymosin $\beta 4$ on Acute Liver Injury Induced by Carbon Tetrachloride in Mice and its Mechanism. Tianjin Medical University (2016).

107. Hernandez-Gea V, Friedman SL. Pathogenesis of Liver Fibrosis. Annu Rev Pathol (2011) 6:425-56. doi: 10.1146/annurev-pathol-011110-130246

108. Tsuchida T, Friedman SL. Mechanisms of Hepatic Stellate Cell Activation. Nat Rev Gastroenterol Hepatol (2017) 14:397-411. doi: 10.1038/ nrgastro.2017.38

109. Barnaeva E, Nadezhda A, Hannappel E, Sjogren MH, Rojkind M. Thymosin $\beta 4$ Upregulates the Expression of Hepatocyte Growth Factor and Downregulates the Expression of Pdgf- $\beta$ Receptor in Human Hepatic Stellate Cells. Ann N Y Acad Sci (2007) 1112:154-60. doi: 10.1196/ annals. 1415.035

110. Reyes-Gordillo K, Shah R, Popratiloff A, Fu S, Hindle A, Brody F. Thymosin$\beta 4$ (TR4) Blunts Pdgf-Dependent Phosphorylation and Binding of Akt to Actin in Hepatic Stellate Cells. Am J Pathol (2011) 178:2100-8. doi: 10.1016/ j.ajpath.2011.01.025

111. Reyes-Gordillo K, Shah R, Arellanes-Robledo J, Rojkind M, Lakshman MR. Protective Effects of Thymosin $\beta 4$ on Carbon Tetrachloride-Induced Acute Hepatotoxicity in Rats. Ann N Y Acad Sci (2012) 1269:61-8. doi: 10.1111/ j.1749-6632.2012.06728.x

112. Li X, Wang L, Chen C. Effects of Exogenous Thymosin $\beta 4$ on Carbon Tetrachloride-Induced Liver Injury and Fibrosis. Sci Rep (2017) 7:5872. doi: 10.1038/s41598-017-06318-5

113. Philp D, Stsurin S, Cha HJ, Moon HS, Kleinman HK, Elkin M. Thymosin Beta 4 Induces Hair Growth via Stem Cell Migration and Differentiation. Ann N Y Acad Sci (2010) 1112:95-103. doi: 10.1196/annals.1415.009

114. Chen Y. The Study of the Effects of Thymosin $\beta 4$ on Hair Follicle Reconstitution[D]. Graduate School of Peking Union Medical College (2016).

115. Cha HJ, Philp D, Lee SH, Moon HS, Kleinman HK, Nakamura T. OverExpression of Thymosin Beta 4 Promotes Abnormal Tooth Development and Stimulation of Hair Growth. Int J Dev Biol (2010) 54:135-40. doi: $10.1387 / \mathrm{ijdb} .082735 \mathrm{hc}$
116. Chen Y. Effects of Thymosin $\beta 4$ on the Growth of Hair Follicle. J Clin Dermatol (2014) 40:457-60. doi: 10.7666/d.Y3075343

117. Hoste EA, De Corte W. Implementing the Kidney Disease: Improving Global Outcomes/acute Kidney Injury Guidelines in ICU Patients. Curr Opin Crit Care (2013) 19:544-53. doi: 10.1097/MCC.0000000000000039

118. Vasilopoulou E, Riley PR, Long DA. Thymosin- $\beta 4$ : A Key Modifier of Renal Disease. Expert Opin Biol Ther (2018) 18:185-92. doi: 10.1080/ 14712598.2018.1473371

119. Zuo Y, Chun B, Potthoff SA, Kazi N, Brolin TJ, Orhan D. Thymosin $\beta 4$ and its Degradation Product, Ac-Sdkp, are Novel Reparative Factors in Renal Fibrosis. Kidney Int (2013) 84:1166-75. doi: 10.1038/ki.2013.209

120. Nemolato S, Cabras T, Cau F, Fanari MU, Fanni D, Manconi B, et al. Different Thymosin Beta 4 Immunoreactivity in Foetal and Adult Gastrointestinal Tract. PloS One (2012) 5:e9111. doi: 10.1371/ journal.pone.0009111

121. Sinwar PD. Overwhelming Post Splenectomy Infection Syndrome - Review Study. Int J Surg (2014) 12:1314-6. doi: 10.1016/j.ijsu.2014.11.005

122. Zheng XY, Lv YF, Li S, Li Q, Zhang QN, Zhang XT, et al. Recombinant Adeno-Associated Virus Carrying Thymosin $\beta 4$ Suppresses Experimental Colitis in Mice. World J Gastroenterol (2017) 23:242-55. doi: 10.3748/ wjg.v23.i2.242

123. Ricci-Vitiani L, Mollinari C, di Martino S, Biffoni M, Pilozzi E, Pagliuca A, et al. Thymosin $\beta 4$ Targeting Impairs Tumorigenic Activity of Colon Cancer Stem Cells. FASEB J (2010) 24:4291-301. doi: 10.1096/fj.10159970

124. Renga G, Oikonomou V, Stincardini C, Pariano M, Borghi M, Costantini C, et al. Thymosin $\beta 4$ Limits Inflammation Through Autophagy. Expert Opin Biol Ther (2018) 18:171-5. doi: 10.1080/14712598.2018.1473854

125. Goldstein AL, Kleinman HK. Advances in the Basic and Clinical Applications of Thymosin Beta4. Expert Opin Biol Ther (2015) 15:S139145. doi: 10.1517/14712598.2015.1011617

126. Liu T, Zhang L, Joo D, Sun SC. NF-kappaB Signaling in Inflammation. Signal Transduct Target Ther (2017) 2:17023. doi: 10.1038/sigtrans.2017.23

127. Sosne G, Qiu P, Christopherson PL, Wheater MK. Thymosin Beta 4 Suppression of Corneal NFkappaB: A Potential Anti-Inflammatory Pathway. Exp Eye Res (2007) 84:663-9. doi: 10.1016/j.exer.2006.12.004

128. Qiu P, Wheater MK, Qiu Y, Sosne G. Thymosin Beta4 Inhibits TNF Alphainduced NF-kappaB Activation, IL-8 Expression, and the Sensitizing Effects by its Partners PINCH-1 and ILK. FASEB J (2011) 25:1815-26. doi: 10.1096/fj.10-167940

129. Martinez J, Malireddi RK, Lu Q, Cunha LD, Pelletier S, Gingras S, et al. Molecular Characterization of LC3-Associated Phagocytosis Reveals Distinct Roles for Rubicon, NOX2 and Autophagy Proteins. Nat Cell Biol (2015) 17:893-906. doi: 10.1038/ncb3192

130. Oikonomou V, Moretti S, Renga G, Galosi C, Borghi M, Pariano M, et al. Noncanonical Fungal Autophagy Inhibits Inflammation in Response to IFNGamma via DAPK1. Cell Host Microbe (2016) 20:744-57. doi: 10.1016/ j.chom.2016.10.012

131. Kyrmizi I, Gresnigt MS, Akoumianaki T, Samonis G, Sidiropoulos $\mathrm{P}$, Boumpas D, et al. Corticosteroids Block Autophagy Protein Recruitment in Aspergillus Fumigatus Phagosomes via Targeting Dectin1/Syk Kinase Signaling. J Immunol (2013) 191:1287-99. doi: 10.4049/ jimmunol.1300132

132. Ji S. Application of Thymosin $\beta 4(\mathrm{~T} \beta 4)$ in the Protective Effect of Myocardial Ischemia-Reperfusion Injury. Chin Med Gui (2011) 17:215-6.

133. Hong Y, Yao Q, Zheng L. Thymosin $\beta 4$ Attenuates Liver Fibrosis via Suppressing Notch Signaling. Biochem Biophys Res Commun (2017) 493:1396-400. doi: 10.1016/j.bbrc.2017.09.156

Conflict of Interest: The authors declare that the research was conducted in the absence of any commercial or financial relationships that could be construed as a potential conflict of interest.

Publisher's Note: All claims expressed in this article are solely those of the authors and do not necessarily represent those of their affiliated organizations, or those of the publisher, the editors and the reviewers. Any product that may be evaluated in this article, or claim that may be made by its manufacturer, is not guaranteed or endorsed by the publisher. 
Copyright (c) 2021 Xing, Ye, Zuo and Li. This is an open-access article distributed under the terms of the Creative Commons Attribution License (CC BY). The use, distribution or reproduction in other forums is permitted, provided the original author(s) and the copyright owner(s) are credited and that the original publication in this journal is cited, in accordance with accepted academic practice. No use, distribution or reproduction is permitted which does not comply with these terms. 